Legal Ethics, Volume 8, No. 1

\title{
Professionalisms Old and New, Good and Bad
}

\author{
ROBERT W. GORDON*
}

I'm very happy and honoured to have been invited to speak at this conference. Our subject is an urgent and important one: how can the legal professions develop realistic, maintainable, sets of ethical standards and practices that are adequate to the functional requirements of the lawyer's task, in an intensively competitive and commercialised environment of practice?

Let me start with three short case histories illustrating how exceedingly difficult and troublesome this task is going to be.

1. Sometime in 2002, agencies of the US government asked the Office of Legal Counsel of the Department of Justice for an opinion on the legal constraints that domestic and international law and treaties to which the US was a party might place on the interrogation of prisoners detained in connection with anti-terrorism operations. On 2 August of that year the OLC issued a memorandum opinion, whose hitherto secret text was leaked in the spring of 2004, which argued three broad conclusions: first, that "torture" as defined by the international Torture Convention and US law codifying it could be construed very narrowly to mean only acts specifically intended to cause lasting physical or mental disability (thus, for example, excluding acts causing intense but only transient pain and merely inadvertent effects such as death); secondly, that any agent prosecuted for torture could assert common law defences of self-defence or necessity because acting to protect a nation under threat; and, thirdly and most sweepingly, that anyone acting under orders of the President had complete immunity, because under the US Constitution the President's authority as commander-inchief of the armed forces to prosecute military operations could not be contained or limited by statute, treaty, customary international law, or indeed anything or anyone else. ${ }^{1}$ The OLC memo argues these remarkable propositions as if they were inescapable conclusions from the legal materials. It does not mention, much less try to refute, the many obvious counterarguments to its own positions, nor the many interpretations of international, domestic, constitutional and common law standing in its way. It betrays no awareness of its own radicalism in claiming, in the company of James I or Carl Schmitt, absolute executive discretion to act above the law; nor of its imprudence in ignoring the risks to the government it advises of

\footnotetext{
* Chancellor Kent Professor of J aw and I cegal I Iistory, Yale University, USA. This article is a slightly revised version of the keynote address to the lirst International Conference on Lawyers' Lthics, "New Perspectives on Professionalism: Fducating and Regulating I awyers for the 21st Century", Fxeter University, UK, 6 July 2004. My thanks go to Kim Lconomides and Julian Webb, organisers of the conference; and to David Luban, Deborah Rhode, Tanina Rostain, William I I. Simon, W. Bradley Wendel and Javid Wilkins, for their comradeship over the years and for their work on professionalism and lawyers' ethics that has pervasively inspired and influenced my own.

1 US Department of Justice, Office of I cegal Counsel, Memorandum for Alberto R. Gonzales, Counscl to the President, 1 August 2002, http://news.findlaw.com/nytimes/docs/doj/bybee80102mem.pdf.
} 
likely responses of outrage from allies and world opinion certain to result if its arguments were publicly asserted and acted upon (though the State Department's Legal Advisor had earlier most vigorously informed the President of potential adverse effects of the policy of exempting the conflict in Afghanistan from the coverage of the Geneva conventions). ${ }^{2}$

2. A year earlier another set of legal memos came to light: opinion letters written by eminent law firms to officers of the Enron Corporation, approving the accounting treatment of transactions that Enron had set up between itself and various limited partnerships (called "special purpose entities") it had created. Enron purported to be selling assets to these partnerships, and making profits from the sales, which inflated its financial statements and caused its stock to go up, and with it the compensation of its executives. In fact the sales were highinterest loans that Enron was making to itself, backed by the collateral of its own stock. Some of the partnerships or "related entities" supposedly independent of Enron were managed by creatures of Andrew Fastow, Enron's chief financial officer, others by Fastow himself; and paid their managers extravagant fees (over $\$ 50$ million to Fastow, in one case). The lawyers' role was to sprinkle the transactions with holy water-that is, to certify to regulators and the investing public that the SPEs and other deals met legal requirements. The lawyers obligingly provided opinions, accompanied by ingenious but far-fetched arguments justifying them, that the entities performed functions of real economic substance (were "true sales"), that they were independent of the parent company, that the participation of Enron managers in the SPEs was squared with the company's conflict-of-interest policies, and that their compensation was adequately disclosed. One legal opinion, for example, reasoned that Fastow need not disclose to the SEC how much he had already earned in fees from managing one of his SPEs because the total amount he would eventually earn was still uncertain. ${ }^{3}$

3. My third recent example comes from the murky realm of corporate tax advice. In recent years lawyers and quasi-lawyers working for both law firms and the giant accounting firms have found among their most lucrative operations to be the devising and marketing of ingenious corporate tax-evasion devices, known as "tax products", and in the writing of legal opinions legitimating them to customers as meeting the requirements of the tax laws. Generally the sole purpose of these products is to lower tax rates to customers; they do not promote any of the substantive economic purposes of the tax code. Many of them will eventually be disapproved when the IRS catches up with them; but in the meantime the customers will have made a lot of money, as well as paid out a lot in fees to the products' marketers. ${ }^{4}$ A single partner earned a leading law firm $\$ 23$ million "issuing 300 opinion letters blessing three types of tax shelters". 5 As a result of a Senate subcommittee investigation, some internal memoranda have recently come to light in which tax professionals candidly assume that their firms' "products" are illegal tax shelters that, if detected, would

\footnotetext{
2 Memorandum, William II. Taft, IV to Counsel for the President, "Comments on Your Paper on the Geneva Convention", 2 l'ebruary 2002, http://www.nytimes.com/packages/html/politics/20040608_DOC.pdf.

3 For guides to the contribution of lawyers and their opinions to the Fnron debacle, sec Roger C. Cramton, "Lnron and the Corporate Lawyer: A Primer on Legal and Lthical Issues" (2002) 58 Business Lamyer 143; Susan P. Koniak, "Corporate Fraud: Sce Jawyers" (2003) 26 Harvard Fournal of Law E Public Policy 195; Robert W. Gordon, "A New Role for Lawyers?: 'The Corporate Counselor after Lnron" (2003) 35 Connecticut Lam Reviem 1185 .

4 See Joseph Bankman, "The New Market in Corporate Tax Shelters" (1999) 83 Tax Notes 1775.

5 I ynnley Browning, "Top Tax Shelter I awyer No I onger at a Big Firm" New York Times 30 June 2004, C1, at C.
} 
be disapproved by the Internal Revenue Service, but that the Service's enforcement is lax and inefficient, and that penalties even if assessed "would be no greater than $\$ 14,000$ per $\$ 100,000$ " in fees paid to the firm. ${ }^{6}$

For our purposes here, perhaps the most interesting thing about these stories is that they are not stories about bottom-feeders lurking at the margins of their profession or rogue lawyers going off the reservation. The Office of Legal Counsel is traditionally the most august and intellectually rigorous of government law offices. The nominal author of its now notorious torture memo has gone on to be a judge on a Federal Court of Appeals. Enron's chief legal advisors on its SPE transactions included the distinguished law firms of Vinson \& Elkins and Kirkland \& Ellis. The tax partner in the third story worked at the accounting firm at KPMG and the law firm of Sidley \& Austin. All of them defend the advice they gave as proper to the role of an advisor-advocate; the tax partner has even written an article explaining that a lawyer must serve the interests of his clients, not the tax system, quoting from St. Matthew: "[n]o man can serve two masters". ${ }^{7}$ These defences are no less insistent despite the fact that the advice given has in fact proved disastrous to their clients. Enron collapsed when investors found out its earnings were largely fictional; its officers including Andrew Fastow are under criminal indictments; the bankrupt company and its law firms are facing over 80 civil lawsuits. The Bush Administration has disavowed the torture memos, but not before the memos impeached before the world the government's claims never to have approved maltreatment of detainees. And the tax partner has been fired and its firm is being sued by its clients.

Such stories appear to render very questionable an account of lawyers' ethics that would identify them simply with "professionalism"-conceived of as virtues inherent in the practice defined by, and exemplified by the conduct of, leading and respected practitioners.

\section{A Primer on Professionalism}

Indeed the general claims of professionalism to establish and enforce a way of life apart from, and superior to, self-interested commercial conduct have fallen upon hard times. It may nonetheless be useful to try to recall what it was about professional ideals and institutions that seemed appealing, with a view to seeing if anything valuable can be rescued for present-day purposes.

"Profession" in English usage first means a vow or oath taken upon entering a religious order; and then becomes extended to mean the group of persons who take such a vow. By the sixteenth century the Latin term "professio", which meant any occupation whatever, had been converted into English. By sometime around the mid-eighteenth century "profession" in the first sense of religious believers had expanded to include anyone entering upon a "calling", and "profession" in the second sense of occupation narrowed to divinity, law and medicine (with the occasional addition of teacher and military officer). The ministry, law and medicine are the prototype "liberal" (implying "generosity in mind and material

${ }^{6}$ US Senate, Committec on Governmental Affairs, Minority Staff Report of the Permanent Subcommittec on Investigations, "US Tax Shelter Industry: 'The Role of Accountants, Lawyers, and linancial Professionals: l'our KPMG Case Studics: FJ IPS, OPIS, BI.IPS, and SC2" (2003) at 26.

7 See Browning, supra n. 5, at C4. 
possessions") or "learned" professions - employments of special dignity linked with university education, gentlemanly social status, some degree of leisure and discretion, and exemplary character. ${ }^{8}$ As Trollope ironically put it, a profession was "a calling by which a gentleman, not born to a gentleman's allowance of good things, might ingeniously obtain the same by some exercise of his abilities". 9

It's only in the nineteenth century that usages close in on those familiar to us now: a profession as "an occupation that regulates itself through systematic, required training and collegial discipline; that has a [cognitive] base in specialised technical knowledge; and that [supposedly] has a[n orientation of service to clients and the public good, embodied] in a code of ethics". ${ }^{10}$ The ideal was first secularised, then democratised. To become a professional conferred elite status, but one deriving from merit recognised by colleagues, not from birth. Like the traditional gentleman, the professional set himself somewhat above and outside market relations; he disdained commerce, and competed for honour and reputation rather than profit; like the gentleman he claimed a capacity for disinterested service arising from his independence, his inability to be bought or dominated by great interests, patrons or employers. Unlike the gentleman, however, he did not disdain work: in fact he borrowed the work ethic, as well as the ideals of collegial conditions of production and of quality, ethics defined according to the shared standards of a community and enforced through self-regulating codes, and techniques for controlling the markets for their services, from the world of skilled craft artisans and their guilds.

Alongside the professions arose the standard functional accounts of their reasons for being. Professionals deliver services whose quality and effectiveness consumers find it hard to evaluate because supplying them requires complex technical knowledge and training and because measures of quality in service and outcomes - indeed what should count as a good or bad or acceptable outcome-are uncertain. Also in most professional relations the provider will face situations where the interests, financial or otherwise, of providers and of his or her clients conflict. These conflicts cannot be resolved by arm's-length bargaining to mutually acceptable contract terms because they are hard to specify in advance and even harder for the patient/client to monitor. Where consumers can't adequately monitor or compare providers, and can't effectively bind them by contracts, there have to be other mechanisms or incentives to bind providers' interests to those of their clients'. External regulatory regimes such as tort law or administrative oversight can supply some of these, but not very effectively. No regulator can hope to undertake ongoing supervision of professions exercising complex discretionary judgements in provider/client interactions and all the many other decisions professionals must make; and the attempt to simplify supervisory functions by reducing them to bureaucratic rules is likely to cripple discretion and thus reduce the value of professional advice and treatment. After-the-fact intervention once it appears that

\footnotetext{
8 lior particularly good overviews of the history of professionalism, see Bruce Kimball, 'The "True Professional Ideal" in America: A Hislory (Cambridgc, Mass., Blackwell, 1992); Samucl I Iaber, The Quesl for Honor and Aulhorily in the American Professions, 1750-1900 (Chicago, Ill., University of Chicago Press, 1991); Harold Perkin, The Rise of Professional Sociely: England Since 1880 (J.ondon, Routledge, 1989).

9 Anthony Trollope, The Bertrams (1867), cited in Perkin, ibid, at 84.

10 Paraphrasc of Paul Starr, The Social Transformalion of American Medicine (New York, Basic Books, 1982), at 15. A large range of occupations by the end of the 19 th century claimed to be professions by virtue of their ability to enforce credentialling requirements through licensed monopolics to practice; but the traditional professions recognised only a few beside themselves as genuine: engineers, academics, civil servants, eventually accountants.
} 
something has gone dreadfully wrong is only a plausible remedy for the grossest kinds of misconduct, and a crude and capricious one at that.

The solution of professionalism to these problems is to instill the ethic of putting the client's welfare first as a primary virtue of the practice of the profession-ie, not so much as an ethical or altruistic obligation defined as such, but as a description of the job: we are professionals, looking after people is what we do; looking after them well is the definition of doing the job well. The hope is that professional training, made habit by experience, reinforced by the teaching of mentors and the example and esteem of peers, will internalise the ethics of quality and care. Of course if a professional proves to be incompetent or self-serving, there is a back-up to the system of informal incentives and pressures: a system of supervision by others in the profession-hierarchical for novices, collegial for initiates; a formal code of ethics, with mechanisms for complaint and adjudication of violations, a disciplinary system with sanctions - and, ultimately, the admittedly crude and insensitive mechanisms of external legal or administrative regulation. The primary and indispensable mechanism of control is the inculcation of an internal self-discipline.

Thus constituted and (horrid word) incentivised, professions have a special role within the advanced capitalist division of occupational labour. Societies have some functions that must be performed by occupations not subject to ordinary market relations and the calculus of profit: there must be islands of work which are relatively insulated from market pressures, of judgements and outcomes that cannot be bought and sold, and are relatively insulated from politics, the clash of self-interested groups and factions; ie, jobs whose occupants' primary orientation is not to making money or pursuing a factional agenda, but who are capable of independent and disinterested judgement. ${ }^{11}$

\section{The Core: Dislinclive Relalions of Aulhorily, Responsibility, and Trusl.}

This way of looking at professionalism sees it as above all generating a distinctive set of relations of authority and trust between the professional and patients/clients who are relatively dependent because they are in a condition of pain, trouble and uncertainty, and must seek the advice and treatment of others more capable than they, presumed by virtue of recognition by their colleagues to have the knowledge, skill and experience to deal with the condition. The client's need generates the demand for the professional's service; this dependence and the client's relative ignorance produce the need to trust in the professional's skill, judgement and devotion to the client's welfare. Because of the character of this relation the professional acquires technical authority (from superior specialised skill) in the relation, "cultural authority" (from being invested with the capacity to define what the client's problem is, and how if at all it may be addressed), and moral authority (from being invested with decision-making power over another's vital interests). This view makes of the professional-client relationship much more than the sale of specialised technical services, and the reason for the profession's authority more weighty than the possession of disparate knowledge. The core of the professional's work is in the cultivation of relations of trust and confidence with people in trouble;

11 Versions of this argument may be found in Tocqueville and Talcott Parsons. Sec Alexis de Tocqueville, Democracy in America in Phillips Bradley (ed), Henry Reeve (trans), (New York, Knopf, 1946), at I: 208, 272-80; II: 98-9 (on the legal profession); Talcott Parsons, "The Professions and Social Structure" in Essays in Sociological Theory (Glencoe, Ill., l'ree Press, 1954), 34-49. 
and the exercise of responsibility stemming from the need to make complex discretionary judgements under fiduciary obligations to others.

\section{Aulonomy and Independence.}

The second distinctive feature of professional work as a calling is its unusual degree of autonomy from external controls other than those imposed by norms or ethical or practice codes of the profession itself. Professional work is, ideally, self-directed and self-regulated to an unusual degree in the division of labour. The requirement of autonomy in work is said to follow from the professional's distinctive relations of trust and authority with clients or patients, and his or her need to exercise independent discretionary judgement. The types of autonomy usually mentioned in this connection are:

-The professional's control over the conditions of his or her work;

- The professional's need for a broad zone of discretionary authority to decide what is best for the patient/client, given the complex peculiarities of each case; the need for preserving trust and confidential relations, and above all the need to make decisions that are genuinely in the patient's/client's best interest, uncontaminated by extrinsic considerations of financial or other interest unrelated to that goal; and

- Guild autonomy — control by associations of professionals themselves of what counts as reliable knowledge and useful training, qualifications for practice, methods of practice, and disciplinary violations.

\section{Collegial Supervision.}

Professional work-relations are also distinctive in that (once a probationary training period has been passed) supervision is collegial rather than hierarchical or bureaucratic, that is regulated, as previously mentioned, by standards collectively developed by fellow professionals (guild autonomy), rather than by rules imposed from the outside and also transmitted through consultative procedures rather than commands.

\section{Repulation and Honour over Money as Primary Goals}

This is a difficult and delicate subject, hard to get a handle on, because it is usually discussed at an unhelpfully high level of abstraction; but it has historically been very important to the self-conception of professionals. An essential part of the ideal of professional work as a calling rather than a job or occupation is that it is directed toward acquiring honour and reputation for skill and character, especially in the eyes of one's professional peers. The professional was supposed to have a distinctive attitude toward money and material success; he was not indifferent to them, did not renounce them as a monk would, but neither did he make them his primary goal or measure his success by their attainment. If wealth should come to him as an incident or by-product of success, well and good; but he must not seek it directly; and financial success or the lack of it was not a reliable sign of his worth as a professional. 


\section{Public and Service Orienlalion}

The final element distinguishing professional from ordinary occupations is that their main ethical orientation is supposed to be toward the welfare of their clients and patients, and towards service of the main social goals that their profession is created to serve-health and the relief of suffering in the case of physicians, justice and social welfare in the case of lawyers. For lawyers especially this set of public obligations comes frequently into conflict with, and has to be balanced against, obligations to serve particular clients.

Professionalism as a set of ideals has lost much if its lustre from its high period, which I would guess was about 1880-1960. The critical view is that professions are nothing more than "conspiracies against the laity" 12 whose real functions are to serve their own interests by controlling the markets for their services. Sceptical economists view professions as stateprotected cartels whose primary purpose is to raise barriers to entry through education and certification requirements, to restrict competition from outsiders, and ultimately to extract monopoly rents by combining to fix prices and the terms of service to clients. Sceptical sociologists see the purpose of professional "projects" not only as attempts to control markets, but to achieve and preserve for themselves a status niche in the class structure, and to legitimate their cultural authority by mystifying their expertise.

Even if one admires and appreciates the good elements in professionalism, it is hard to deny that they are now under tremendous pressure to survive. Autonomy, disinterested judgement, primary orientation to independent criteria of judgement and public values are at serious risk from competition and the dominance of commercial values. Both insiders and observers have argued that these developments represent irresistible trends caused by uncontrollable forces. The inevitable results, they suppose, must be the increasing absorption of previously "autonomous" professionals into "heteronomous" work environments in which their work is structured by externally enforced Tayloristic rules, rather than exercises of independent discretion, their special relationships with clients and patients are fragmented and intruded upon, their status is "proletarianized" as they become dependent employees of large organisations. ${ }^{13}$ Other observers, seeing capitalist market relations rather than bureaucratic work-organisation as the wave of the future, celebrate the collapse of professional mystiques of authority and claims to a morality above that of the market-place, and welcome the open, unabashed, competition for the business of "consumers" as the mechanism that will increase access to professional services and quality and efficiency in their delivery. ${ }^{14}$

Is there any reason, in such a climate of critiques of professionalism and either gloomy or enthusiastic predictions of its demise, to try to salvage something of the old professional ideals? I am quite certain there is, and not just because professionalism holds out the promise of a morally attractive way of life. It does that: but ultimately professionalism has to be justified on some other basis than that it's a good deal for professionals! The basic justification is what it always was, that professionalism solves problems that markets not only cannot solve but often exacerbate, the problems of supplying the social need for disinterested

12 Bernard Shaw, The Doclor's Dilemma (1911), Act. 1.

13 An exceptionally astute recent work of this kind is Llliott A. Krause, The Death of the Guilds: Professions, States and the Advance of Capilalism, 1930 to the Present (New I Iaven, Conn., Yale University Press, 1996).

14 See, eg, Regina L. Herzlinger, Market-Drizen Health Care (New York, Addison-Wesley, 1997). 
judgement that is not for sale to the highest bidder, for a primary ethical orientation towards service of people in great need (a need that could easily be exploited by the unscrupulous) and toward criteria of quality and service of the public good as well as cost-effectiveness and profit. Market forces cannot reliably produce these goods; and regulation cannot compel or guarantee their production. We still need people with the appropriate internal orientation to an ethic of service, care and quality; and we are not going to attract or produce them through profit incentives or micro-management, at least not alone. So the professional ideal is starting to look very appealing again just as the old conditions for its effective institutionalisation are eroding. The agenda should not be to scrap it, but to search for ways to nurture it under the new conditions, to look for new modes of articulating the ideals, institutionalising them with incentives and good examples and effective enforcement mechanisms, socialising lawyers into them.

\section{Law Schools as Sources of Revived Professionalism}

In my country as well as yours, judges and bar associations are looking to the law schools as places from which to begin the repair of professional practices. One thing is clear. If law schools are viewed as the place where ethical education, calling for serious ethical reflection by lawyers on their profession, ends as well as begins, the project of ethical education will fail.

Socialisation into ethical dispositions and behaviour is a lifetime enterprise, in which the crucial stage is probably apprenticeship. It is appropriate to assign some responsibility for helping to inculcate professional ethics to law schools. But law schools are only a place to begin such training. If training stops there, it will be useless, and perhaps worse than useless, because it will reinforce the cynical belief that professions only get serious about ethics in settings where there are no consequences for deviating from them, and no sacrifices to be made for adhering to them. The crucial period is apprenticeship: the novice's first exposure to concrete settings, practical applications, real incentives, and senior lawyers who are relevant models for imitation.

Law schools have traditionally not done a good job teaching professional values. We all know why this is so. The faculties, mostly refugees from practice, avert their eyes from the careers and practice settings in which their graduates will spend most of their lives. In America we do a pretty good job of preparing students to be (or argue before) appellate judges, legislators and philosopher-kings. We don't teach them a lot about being lawyers except writing research memos and arguing cases. We assume they will learn that later on. Students for their part are sceptical about ethical training. They assume ethics is either a matter of ordinary morality, acquired in early childhood if ever, which at this point they either have or don't have; or else it is a matter of rule-following. Of course it's neither: persons of exemplary honesty, fairness and generosity in personal dealings can be real stinkers in professional settings. As for the rules, they at best set a minimum standard of ethical conduct. More important, if your rules are like ours, they are least helpful where most needed, when the lawyer's obligations to clients are in greatest tension with obligations to the legal system.

Yet the professional responsibility course until recently was taught as a course in the disciplinary rules. Can law schools do better? Sure they can, or we wouldn't be here. They

HeinOnline -- 8 Legal Ethics 302005 
are already doing much better. Law school clinics, for one thing, make it possible to begin socialising students early into ethics of care, loyalty and confidentiality: actually having to take on responsibility for someone in trouble-more responsibility than a firm would give them for many years - is a breathtakingly educational experience. Clinical work presents live everyday ethical dilemmas - the conflict between what a client says he wants and what he actually seems to need, the temptations to stretch fact and law to the limits or beyond them to fit the client's situation into something qualifying for a legal solution, the problem of the lying client or witness, the problem of indifferent, unresponsive or actually hostile legal agencies and tribunals.. In the clinical setting, the day's ethical problems, generated by the caseload, can become the objects of shared reflection and analysis.

Academic courses have a role too. One thing law schools can probably do better than practice settings is education in the structural determinants of lawyers' situation and lawyers' practices. Ethical orientations after all are only partly a matter of internal disposition. They are as much or more importantly a function of structures and incentives embedded in markets, institutions, and cultural systems. Almost everyone recognises that what seem to be increasing pressures on lawyers to engage in dubious behaviour-overbilling clients, dumping lower-fee in favour of higher-fee clients in cases of conflicts, taking "aggressive" positions with regulating and taxing authorities, allowing corporate clients to skate near or over the borders of legal conduct.

In corporate law, of course, both "lawyers" and "clients" are organisations, not individuals, or rather individuals embedded in organisations, and making decisions and looking for cues to organisational leadership and incentives. If ethical precepts point one way and practical incentives another, the precept is going to bend; if the associate finds a smoking document that in substance matches the discovery request, but as to which there is a nitpicking literalistic argument that it doesn't, the crucial element is going to be how the associate thinks the supervising partner is going to react if he produces the document. If the partner is seen over-billing his clients, the associate is more likely to pad his time sheets; everybody does it. Do the partners care about ethical practice? Is engaging in it a positive or negative factor in promotion and share of partnership profits?

But though a course in economics and sociology of professional and client organisations and markets is crucial, it is not enough. Law schools have got to be the place, at least the first place, to subject the ethical principles themselves to critical scrutiny-preferably in dialogue with, and with the active engagement of, practitioners. Some ethics teachers have been very successful in examining how the lawyer's differentiated role-morality can be reconciled with, if it can at all, principles of ordinary—Kantian, Aristotelian, utilitarian, or any other-morality.

\section{Limits on Professionalism as an Ethical Guide}

The basic problem however is that "Professionalism", by and for itself, is not enough. It is in most ways too elastic and contested a concept to give much real purchase on how to devise a programme for socialising lawyers into a culture of ethical and public-regarding behaviour. The range of meanings is very broad. To some it means simply civil and courteous behaviour to courts and opponents; to others, meeting high technical or craft standards in service to clients; to a few, satisfying very exacting ideals of independence, public service, and actions meant to ensure access to justice. 
Principles of professionalism expressed in codes of professional regulation are least helpful where most needed. The principles are most robust and helpful in addressing situations where lawyers' self-interest is likely to conflict with clients' interests-where they stress obligations of competence, loyalty and confidentiality, and warm advocacy. They tend to be most un-illuminating in addressing situations where the lawyer's promotion of clients' interests may do damage to the legitimate interests of third parties and especially to the integrity of the procedural framework and the fulfillment of the substantive purposes of the legal system. Codes of professional ethics are most troubling when they seem to give lawyers a special licence to help their clients sabotage the legal framework. Any legal ethics course has to be partly a course in jurisprudence. As lawyers we are supposed to pursue our clients' interests "within the bounds of the law". But what is the "law" whose bounds set the limits of our clients', or our own, self-interested action? How constructed? One view, much in vogue these days among corporate lawyers even after the Enron el al. scandals, is that we can help the client do anything that, in the unlikely event the client is ever caught doing it and a court or agency tries to impose a sanction, we could make a not-completely-laughable-evenif-farfetched-argument that it was legal; that is, any behaviour to which we would be able to put on a colourable defence, even if we were pretty sure it would lose if put to the test. My own view is that the greatest mischief comes from this "adversary system excuse", the completely inappropriate extension of the criminal defence lawyer's role to settings such as corporate counselling where none of the conditions for the beneficial effects of the advocate's role-presentation in open court, on an open record, with an adversary to present counterproof and contrary legal arguments, and a neutral umpire deciding —obtain.

Look at what happened in the three case histories I began with. They have some elements in common: in all three cases the people to whom the lawyer's advice responds (I will not call them the "clients" because it's not clear that they actually do properly represent the clients or constituencies on whose behalf and in whose interests the advice is purportedly given) are trying to avoid or minimise legal constraints on their conduct, and asking their lawyers for help in doing that. Tax products are marketed to corporations whose agents have identified taxes as a cost to the firm, which it's the job of inside counsel, with the help of outside tax consultants, to reduce; many have stated goals "to reduce our tax liabilities by $30 \%$ this year". Enron's managers wanted to inflate the apparent value of their earnings to the markets: the obstacle they faced was a set of securities laws and rules whose purpose is to make the actual state of corporate finances transparent to the markets. The lawyers' and accountants' role was to make their finances opaque to the markets so that debts and losses would show up as profits; and, just as important, to provide a fig leaf of legitimacy in case they were caught, just enough cover to enable a defence of good faith or advice of counsel to escape criminal or civil liability for fraud. The torture memos seem to be responsive to officials who want to know how much pain they can inflict without becoming vulnerable to criminal convictions. (Some of the advice was not perhaps as competent as it might have been: the Pentagon's torture memos advised that lower-level pain-inflictors might assert the "Nuremberg defence" of following superiors' orders, apparently unaware that at Nuremberg following orders was held not to be a defence, and that several who asserted it were hanged.)

The government's memos are egregious because it's pretty well accepted that government lawyers, especially in so august an operation as the Office of Legal Counsel, are supposed to 
remember that they are servants of their country and its Constitution, not simply of the officials who consult them. But in the Enron case as well, the lawyers confused the managers who sought their help in gimmicking their financial reports with their real client, the corporation and its stakeholders. Most important, in all three cases, the lawyers involved seem to have had no conception of, or at least paid no attention to, law as embodying norms rather than rules to be gamed, law as expressing public values and trying to implement commonly adopted social objectives, law as enacted for any reasons other than to trip up honest businessmen and conscientious security services. The lawyers took the economist's view of law as prices, legal penalties as tariffs on conduct discounted by the probability of their enforcement; and saw the lawyer's task - indeed the lawyer's vocation — as that of helping clients get round the law. In cases like Enron's, a host of professionals, accountants, stock analysts, investment bankers and a flotilla of lawyers_-all doing their jobs as prevailing professional conventions made them think they were supposed to do them, collaborated to facilitate a series of giant swindles. The aggregate result of such activities, over time, is the nullification of law by the extra-parliamentary techniques of underground resistance. It works: for example corporate tax revenues in my country are increasingly uncollectable: promotion of aggressive tax shelters is estimated to have cost the treasury over $\$ 300$ billion last year. The rest of us taxpayers will eventually have to make up the deficit. Sure-the government could respond, if it wanted to, by closing loopholes and imposing stiffer penalties. But its responses will be fought by the same professional maquis, through the same techniques of guerrilla warfare. No legal regime can make itself effective against determined resistance.

The pervasiveness of law-defiance by means of lawyers poses a very big problem for education in legal ethics, given that law schools are only the beginning of a lifetime of socialisation into and critical reflection on the ethics of professional practice. The crucial loci for learning are where careers are made, persuasive role-models are found, and practical learning takes place-which for most lawyers (here for solicitors at least) means a firm(defined loosely: it might be a prosecutor's office or a corporate general counsel's office). But the economic goals of firms, making as much money for the partners as possible in competition with other firms, cut against the ethical obligations of lawyers to sustain the spirit of the laws. The desire for professional respect and reputational capital is not strong enough to overcome those incentives - especially these days when the principal going form of reputational capital is a high place in the ranking of firms by earnings-per-partner.

So there have to be leverage points outside the firm. Some are intra-professional, such as speciality professional associations: in the US some state associations of tax lawyers have taken a leading role in defining and lobbying for enforcement to restrict tax-evasion schemes. The courts, mindful of the procedural virtues of the rule of law as well as reducing timeconsuming and annoying strategic manoeuvring, have taken a hand in policing nasty lawyer tricks in litigation. But as we all know it's very difficult to cartelise ethical standards; and, even when we do, professional associations have neither will nor capacity to enforce them against high-level violators. In our system, big firms are never disciplined by the bar. The only effective sources of discipline are regulators' sanctions, civil liability, and malpractice liability, If - and apparently only if - there's a plausible threat of sanctions, there's pressure to created internal cultures of compliance at the firm level. We now have one state, New York, that holds firms liable for ethical violations of its members. In response to new regulations and malpractice suits, many firms are now beginning to develop "ethical 
infrastructures". The biggest challenge, as the Clementi review indicates, ${ }^{15}$ is to develop regulatory regimes that cut across competing professions and providers of legal-financial services in many different countries.

So this is a very difficult enterprise we are undertaking: trying to figure out how to inculcate a culture of furthering law's valuable public purposes among professionals whose economic incentives often cut the other way, and who have developed an elaborate set of high-minded reasons, founded on a wholly misplaced analogy of the legal counsellor's role to the criminal defence lawyer's, for facilitating and rationalising some of their clients' most anti-social impulses. This project is extremely important, because the stakes are so very high, not just for society and the rule of law, but for the moral and existential well-being of the people involved. Current practice conditions, even in the highest precincts of the profession, create more ethical strain than it's reasonable to ask ordinary lawyers to bear. Being a good person and a good professional always requires a certain amount of courage and fortitude: but it shouldn't have to require heroism to struggle to act as a reasonably decent and truthful person in the ordinary tasks of life and work.

15 Sec Report of the reviem of the regulalory framework for legal services in Fingland and Wales (December 2004), at www.legal-services-review.org.uk. 